UDC: 378

\title{
INNOVATIVE METHODS AS AN IMPORTANT PART OF LEARNING FOREIGN LANGUAGES
}

\author{
O. V. Ovadiuk \\ Kyiv, National technical university of Ukraine "Kyiv polytechnic institute" \\ olkind@i.ua
}

\begin{abstract}
The article deals with the role of information technologies in learning foreign languages. The paper states the great importance of IT in the learning process as well as in the process of raising motivation among students to a higher level. It also describes different multimedia methods among which the outline of video lessons, role-playing game lessons, distance learning and project based learning have the leading role. The article also points out that due to the application of multimedia technologies the possibilities of modern methods of learning foreign language are considerably broadened and diversified. The content of lessons with the help of IT is enriched, the rate of realization is high, and a teacher gets the possibility to use educational time more effectively, to invent the original methods of teaching and increase the volume of educational material for students' mastering and usage.

The article analyses various language activity categories with the help of different types of modern technologies and their positive effect on language learning efficiency.

It also states that the application of multimedia materials and computer networks abbreviates time of studies by almost three times, and the level of memorizing through the simultaneous use of images, sound and text is 30-40 percent more. Due to the use of multimedia means, students perfect all aspects of language: phonetic, grammatical, lexical and communicative. This allows mastering language material, language skills and abilities more effective and quicker.
\end{abstract}

Key words: Power Point presentation, project based learning, information technologies, educational process, multimedia technologies, teaching methods, foreign language learning.

Introduction. Information technologies stand out as a requirement of present time, as they burst into all spheres of our life rapidly. Introduction of new technologies into the educational process was always considered a progressive step that promoted motivation of learning. It is possible to raise the level of language education of students by means of bringing in the newest information technologies including multimedia assets as well.

In the last few years, our society undertook a considerable step forward. IT substantially influenced all systems of education, including content, forms and methods of studies.

Wide application of information and communication technologies became a norm for most of the higher educational establishments in the whole world. As politics of the educational systems in the field of language study heads not only for the young people to study as many languages as possible, but also for the development of abilities, that allow to be mobile, informed and communicative, use of multimedia means is very actual.

Multimedia technologies can be described as package of video, audio and other means of reflecting information that is integrated in an interactive software environment. Multimedia means allow to involve almost all five senses of students, combining the printed text, graphic image, movable video, static photos and audio-record. It is well proven that application of multimedia materials and computer networks abbreviates time of studies almost three times, and the level of memorizing through the simultaneous use of images, sound and text is 30-40 percent more. Due to the use of multimedia means, students perfect all aspects of language: phonetic (CD - London Linguaphone Course), grammatical (CD - English Grammar by Murphy, - Business Grammar Builder), lexical (multimedia Encyclopaedia - Britannica) and communicative, that allows more effective and quicker mastering of language material, language skills and abilities.

The aim of this article is to describe the role of information technologies in learning foreign languages, to state the great importance of IT in the learning process as well as in the process of raising motivation among students to a higher level. The article is called to enroll different multimedia methods, among which the outline of video lessons, role-playing game lessons, and project based learning have the leading role. 
The implementation of new methods of learning that provide the development of communicative, creative and professional competences and stimulate the requirement of future specialist in self-education based on the content and management of educational process is required from modern educational establishment nowadays. The aim of foreign language studies in the higher educational establishment is forming professional communicative competence among students with the help of development and perfection of all types of language activity: reading, speaking, writing and listening [1].

As practice shows, a computer, from all the existent means of study, is the best choice to be implemented into the structure of educational process, which meets all the didactic requirements and maximally approach the process of learning foreign languages to the real terms. A computer is capable to provide all-round (enter, current, final) control of educational process as well.

Another advantage of a computer is the ability to accumulate statistical information during the educational process. Analyzing statistical data (amount of time spent on correcting errors, right/wrong answers, implementation of separate tasks, etc.), a teacher judges the degree and quality of student's knowledge.

Computers also create favourable possibilities for organization of self-assessment work of students at a lesson of foreign language. Students can use a computer both for the study of separate themes and for self-control of gained knowledge.

Power Point Presentations. One of the most successful examples of computer technology usage is a Power Point presentation.

Foreign language multimedia presentation is a way of showing the creative, newly made, and adapted for the certain level of student's language information as the logically completed selection of slides on certain topics by a teacher. Multimedia presentation is based on the use of audiovisual possibilities of computer technologies.

There is a general algorithm of multimedia presentations creation. Accordingly, it is very important for a teacher to follow such steps:

1) to define pedagogical tasks which are going to be solved by means of the created multimedia presentation;

2) to think over the aim and task of the slides creation;

3) to put themselves in the place of students, taking into account their potential possibilities;

4) to pick up illustrations (pictures, sounds), using multimedia possibilities of computer (processing of collected earlier information or a search for new one);

5) to think over the text's content considering the basic requirements to all multimedia presentations;

6) to write down the script of multimedia presentation;

7) to create the structure of multimedia presentation, using the necessary computer programs;

8) to apply animation and voice effects;

9) to analyze and estimate the prepared presentation in accordance with the requirements of multimedia presentations.

The material positioned as electronic presentations substantially extends possibilities of ordinary educational means due to the use of audio and video tracking and effects of animation. During work with a computer, a student's acoustic and visual channels of perception are involved, that allows increasing not only the volume of the perceived information but also durability of its mastering [2].

Examples of what can be created on the basis of a PP Presentation

1. Flash-cards on a certain topic.

2. Reports on the books and articles.

3. Scientific presentations that illustrate research work of a student.

4. Creation of student's portfolio.

5. Demonstration of graphs diagrams and charts.

6. Tests. 
Power Point presentations are used in educational establishments of different levels and specifics such as:

1) objects of study in a course of information and of communication technologies;

2) means of electronic and paper support in the process of educational orientation and explanation of the material by the teacher as well as reports of students, graduate students, listeners; also they are used to exchange education experience.

With the aim to reduce typical mistakes certain requirements for Presentations created on the basis of MS Power Point are developed.

1. Selection of text and graphic material:

1) arrange and laconically present it;

2) write a script and create presentation on the topic given.

2. Structure of presentation and navigation:

1) title slide pointing to the establishment, the theme and the author;

2) structures of slide titles: complexity;

3) slide with the table of contents with hypertext links to the beginning of the sub items and button of return to the title;

4) in a sub item: every slide contains the button of return to a previous slide and the last one - the button of return to the table of contents ;

5) hyperlinks to the online sources and programs.

3. Artistic composition:

1) intenseness of no more than $1 / 3$ of screen area, that is why list goes the first, and details about every object go separately;

2) the main object is located in the proportion of golden section;

3 ) the semantic center is placed below and more to the right.

4. Parameters of the text style:

1) no more than three variants of fonts that differ in type, size or boldness;

2) laconism: no more than two lines in a title or a list row, no more than 6 rows in a list.

5. Colour spectrum, contrast and brightness of the image:

1) accordance of the colour palette with relative visibility of the image objects;

2) consistency of the colors used for the indication of similar objects;

3) accordance of the colours to the visual associations: red - danger, yellow examination, green - the one that allows, violet - fantasy, black - strictness, white - ideal exactness, etc.

6. The synchronized sound / speech accompaniment (if using the microphone).

7. Animation is for bringing in the attention to the change of the slide.

Now let us consider the methodological aspects of creation of educational presentations. The type of such presentation depends on the role of that presentation in the educational process at the lesson. Presentation can be supporting, or fully functioning. A teacher uses supporting presentation during the explanation of new material, using a computer technique instead of placards, maps, handing material. In this case, the basic informative role belongs to the teacher. A fully functioning presentation takes away the main role at the lesson. The teacher just prepares students for working with new material, states the topic and aim of the lesson, and some moments that need special attention, while learning new material. Then, students learn new material on their own, with the help of the presentation. At the end of the lesson, the teacher conducts a discussion on the topic, specifying certain moments, answers the question of students and works out the summary of the lesson. It is very useful to have computer tests, as an addition to such presentations. The test will be useful both for self-assessment of students and for control of their knowledge by the teacher. Creating supporting presentations, the basic elements of slides will be graphic objects: pictures, charts, diagrams, graphic arts and tables. To a lesser degree, videos-fragments are used. It is related to such fact that video-fragment needs to be watched and listened to. Thus, a high synchronicity is needed in all the students' efforts, so that some of them have not experienced the technological pause, which has not been planned by the teacher in the study time. Project apparatus and interactive boards are very useful for such presentations. In this case, videos-fragments acquire a 
greater value. Multi-text information should not be used in presentations of supporting type, because it can also results in an unplanned pause, since the speed of working with the text varies greatly among different students.

A teacher replaces possible text information with the explanations.

So, the supporting presentations are used to visualize and make new material at the lesson clearer.

Fully functioning presentations contain considerably more text information and nearly the same amount of graphic support. Audio and video support is very useful in this type of presentation. Audio corresponds with the text on the slide. It is done for those students whose aural memory prevails.

It should be remembered that text must be distributed on slides in small portions and supported by corresponding pictures, charts images, etc. In such case, text information is better perceived and understood by students. Not a single slide of fully functioning presentation, except a slide with a film object, must contain objects without text tracking. Such slide will be blank, i.e. not clear to the student. The quantity of animation should not be excessive. Animation can be useful on a title slide, and very harmful on the other. The reason is that animation tends to distract attention from the material, which is studied.

If students have textbooks, then material of a presentation should be maximally concerted with them. It is recommended to create a presentation based on the texts from such textbooks.

Video. Video plays an important role in the study of a foreign language. It is used for auding (perception of foreign language by listening). It helps to create dynamic visualization that makes a lesson more interesting. However, the ordinary watching of films will give no effect. For this methodology to work out, it is needed to implement it correctly:

1. Work with video must include three basic stages: before-demonstration stage, demonstration itself and after-demonstration stage.

2. The first stage is called to exclude language difficulties of movie text perception. New words and word combinations should be introduced, their usage should be analyzed as well as authentic colloquial forms and linguistic country-specific realities should be taken into account.

3. It is necessary to do the number of the exercises on a certain sequence, dynamics of cooperation and behavior of characters, related to further translation of a content before watching the film. It is also possible to do the exercise on description and estimation of information the film contains.

4. The demonstration stage of video film must be accompanied by high activity of a student. It is possible to do a few tasks while watching: to do supporting records, or to write down supporting words and phrases, etc.

5. The teacher has to control the understanding of content and language means used in a film, after viewing it, spare the special attention to translation of a content. It can be done on behalf of different movie characters. A very interesting method is called "a fly on the wall", that envisages a story on behalf of an extraneous observer, who watched everything that took place according to the plot.

6. It is expedient to conduct a role-playing recreation of a text (especially, if there are many dialogues and polylogues in the movie), discuss a situation, possible ways of solving a problem (if there is one) and many other methods and exercises.

Project-based Learning. In the modern world, literacy consists of number of skills (to express your own opinion, wishes, and necessities orally; to read and write; to find and to choose necessary information; to understand different views that often conflict with each other) [5]. The evaluation of knowledge and abilities is the process of learning, not the outcome; the educational process is not preparation to life, it is part of life, for this reason, participating in it must bring pleasure.

One of such interesting forms of studies is non-standard lesson of foreign language. Such lessons impress by their variety: lessons-excursions, business games, lessons-dialogues, lessonspress-conferences, lessons-contests, etc. The most important condition of efficiency of realization of non-standard lessons of foreign language is the presence of positive emotions [6]. You cannot get 
unsatisfactory mark during these lessons, as a rule. The method of projects plays crucial role in the improvement of mastering of foreign language, and in the increase of motivation among students. The basic lines of creation of a project in the process of learning foreign language are: creation of real vital situations; their aiming at the development of imagination and enriching of knowledge; obligatory motivation; development of skills; learning how to collaborate successfully; adequacy of tasks for every person, who participates in a project

The method of projects is not a Ukrainian invention. American professor Kilpatrick [3] considers that the process of realization of a project knowledge not only acquire the special durability and realization, but also content-addressable and connected with getting pleased which gives an impact to the new search. A search in turn causes new associations, new projects.

A game modelling during foreign language lessons assists the establishment of a psychological contact, harmonious development of interpersonal attitudes, creative initiative, developing flexibility of perception of material, positive mood, imagination and ability to listen to an interlocutor. Participating in all types of innovative games develops motivation to the changes, creates "reflexive space "as method of student emancipation" [4].

Role-playing based teaching. Role-playing is mostly used when it is needed to analyze a problem and find the best solution. The practice can be tried in different fields like engineering, language learning, etc. Language and engineering students are given a scenario and different requirements to solve a problem, and make a decision in a given environment. For example, in teaching interpreting the role of interpreter can be explained by the role-playing technique. It can be interpreting at a conference, or during a meeting, etc. Similar kind of technique can be applied in every possible course.

Conclusion. In the process of a study the outline of all main information technologies used in learning foreign languages was given, the great importance of IT in the learning process as well as in the process of raising motivation among students was proven as well. The article examined different multimedia methods, among which the peculiarities of video lessons, role-playing game lessons, and project based learning have the leading role.

Application of multimedia interactive technologies substantially improves the quality of lesson material and raises the motivation, at the same time individualizing the language learning.

Taking into account all the above-mentioned factors we can draw a conclusion, that in the modern society, where it is difficult to surprise students by something, the use of IT can become an additional stimulus, the so-called "spark", that will introduce the originality into the educational process, inspiring students for further creativity and motivate them to a higher level. Therefore, the ability of a teacher to use IT in the educational process became one of the substantial parts of professional competence.

\section{REFERENCES}

1. Littlewood, W. (1992). Teaching Oral Communication: a Methodological Framework. Oxford, Great Britain: Blackwell, 82-83.

2. Fisher, D. (2003). Using PowerPoint for ESL teaching. The Internet TESL Journal, 9(4). Retrieved from: http://iteslj.org/Techniques/Fisher-PowerPoint.html

3. Coleman, J. (1992). Project-based learning, transferable skills, information technology and video. Language Learning Journal, 5, 35-37.

4. Keller, J. (1983). Motivational Design of Instruction. Instructional Design Theories and Models: An Overview of Their Current Status. Hillsdale, NJ: Lawrence Erlbaum Associates, 383-434.

5. Crookes, G. (1991). Motivation: Reopening the Research Agenda. Language Learning, 41, 469-512.

6. Gardner, R. (1985). Social Psychology and Second Language Learning: The Role of Attitudes and Motivation. London, Great Britain: Edward Arnold, 355.

\section{О. В. Овадюк. Інноваційні методи, як важлива частина навчання іноземній мові.}

Стаття розглядає роль інформаційних технологій у вивченні іноземних мов. Вона підкреслює велику важливість ІТ в навчальному процесі так само як і в процесі підвищення рівня мотивації студентів. У статті наводяться описи різних мультимедійних методів серед яких схема відео-уроків, рольові ігри, і проектне навчання грають основну роль.

Стаття також підкреслює, що завдяки застосуванню мультимедійних технологій можливості сучасних методів вивчення іноземної мови значно розширюються і стають більш різноманітними. Вміст уроків за 
допомогою IT стає багатше, темп роботи на уроці прискорюється, і викладач отримує можливість використовувати учбовий час ефективніше, щоб створити оригінальні методи навчання і збільшити об'єм освітнього матеріалу для засвоєння і використання студентами.

У статті аналізуються різні види мовленнєвої діяльності за допомогою сучасних технологій i вивчається їх позитивний вплив на ефективність навчання іноземній мові.

Так само підкреслюється, що застосування мультимедійних матеріалів і комп'ютерних мереж скорочує час необхідний на навчання майже в три рази, і рівень запам'ятовування, завдяки одночасному використанню зображень, звуку і текстів збільшується на 30-40 відсотків. Це дозволяє вдосконалювати мовленнєві навички і здібності ефективніше і швидше.

Ключові слова: презентація Power Point, проектне навчання, інформаційні технології, освітній процес, мультимедійні технології, учбові методи, вивчення іноземної мови.

\section{О. В. Овадюк. Иновационные методы, как важная часть обучения иностранному языку.}

Статья рассматривает роль информационных технологий в изучении иностранных языков. Она подчеркивает большую важность ИТ в обучающем процессе так же, как и в процессе повышения уровня мотивации студентов. В статье приводятся описания различных мультимедийных методов среди которых схема видео-уроков, ролевые игры, и проектное обучение играют основную роль.

Статья также подчеркивает, что благодаря применению мультимедийных технологий возможности современных методов изучения иностранного языка значительно расширяются и становятся разнообразнее. Содержимое уроков с помощью ИТ становится богаче, темп работы на уроке ускоряется, и преподаватель получает возможность пользовать учебное время более эффективно эффективнее, чтобы создать оригинальные методы обучения и увеличить объем образовательного материала для усвоения и использования студентами.

В статье анализируются различные языковые виды деятельности с помощью современных технологий и изучается их положительное влияние на эффективность обучения иностранному языку.

Так же подчеркивается, что применение мультимедийных материалов и компьютерных сетей сокращает время необходимое на обучение почти в три раза, и уровень запоминания, благодаря одновременному использованию изображений, звука и текстов увеличивается на 30-40 процентов. Это позволяет совершенствовать языковые навыки и способности эффективнее и быстрее.

Ключевые слова: презентация Power Point, проектное обучение, информационные технологии, образовательный процесс, мультимедийные технологии, учебные методы, изучение иностранного языка. 